Dicle Tıp Dergisi / Dicle Medical Journal (2017) 44 (1) :1-11

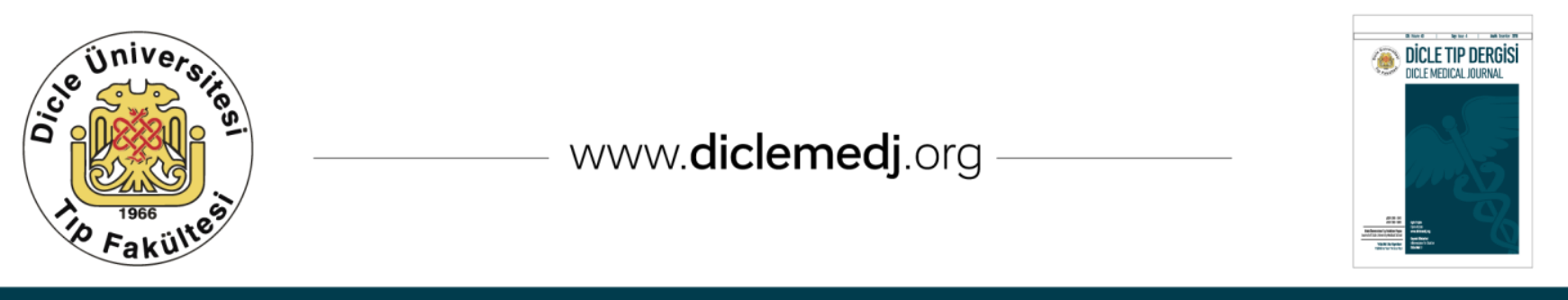

Özgün Araştırma / Original Article

\title{
Sağlık Hizmetleri Meslek Yüksekokulu Öğrencilerinin Sağlıklı Yaşam Biçimi Davranışları ve Etkileyen Faktörler
}

\author{
Mehmet Ali Şen', Ali Ceylan², Mehmet Emin Kurt ${ }^{3}$, Yılmaz Palancı², Cihan Adın² \\ 1 Dicle Üniversitesi Atatürk Sağlık Hizmetleri Meslek Yüksekokulu Diyarbakır, Türkiye \\ 2 Dicle Üniversitesi Tıp Fakültesi Halk Sağlığı Anabilim Dalı Diyarbakır, Türkiye \\ 3 Dicle Üniversitesi Íktisadi İdari Bilimler Fakültesi Diyarbakır, Türkiye
}

Geliş: 26.04.2016; Revizyon: 06.02.2017; Kabul Tarihi: 10.02.2017

Özet

Giriş: Bu çalışma Dicle Üniversitesi (D.Ü.) Atatürk Sağlık Hizmetleri Meslek Yüksekokulu 1.sınıfında öğrenim gören öğrencilerin sağlıklı yaşam davranışı biçimlerini belirlemek amacıyla tanımlayıcı olarak yapılmıştır.

Yöntemler: Araştırmanın evrenini Sağllk Hizmetleri Meslek Yüksekokul'u 1.sınıf öğrencileri (251 öğrenci) oluşturmaktadır. Katılımcılara demografik verileri içeren yapılandırılmış bir anket ile Walker tarafından düzenlenen ve 2008 yılında Bahar ve arkadaşları tarafından Türkçe geçerlik ve güvenirlik çalıșması yapılmış olan "Sağlıklı Yaşam Biçimi Davranışları Ölçeği II" (SYBDÖ) uygulanmıştır. Verilerin değerlendirilmesinde sayı-yüzdelik hesaplama, ortalama, t testi ve korelasyon analizi kullanılmıştır.

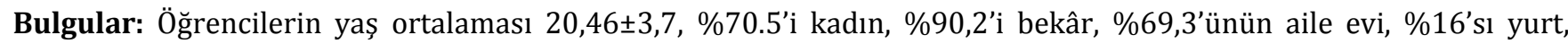
\%14,7'side öğrenci evinde kalmakta, \%27,9'u okurken ek bir işte çalışmakta, \%77,7 sinin anne eğitim durumunun en fazla ilkokul olduğu saptanmıștır.

Öğrencilerinin toplam SYBDÖ puan ortalamaları orta düzeyde bulunmuştur $118,0 \pm 21,0$. Anne eğitim durumu yüksek olan öğrencilerin, kişilerarası ilişki puan ortalaması yüksek olmakla birlikte istatistiksel açıdan anlamlı bulunmamıştır. Anne eğitimi yüksek olan öğrencilerin beslenme, kişilerarası ilişkiler ve toplam puan ortalaması anlamlı bulunmuştur $(\mathrm{p}<0.05)$.

Sonuç: Çalışma yaptığımız üniversite öğrencilerinin SYBDÖ puan ortalamalarının orta düzeyde olduğu ve annenin eğitim düzeyi ile ilişkili olduğu sonucuna varılmıştır. Sağlık sektöründe görev alacak olan öğrencilerin sağlığı geliştirme davranışlarının önemini kavramaları ve bilgilerini davranışa dönüştürmeleri yönünde eğitimler yapılması gerekmektedir.

Anahtar kelimeler: Sağlıklı Yaşam, üniversite öğrencisi, sağlıklı yaşam biçimi davranışları.

\section{DOI: $\operatorname{xxxxxxxxxxx}$}

Yazışma Adresi / Correspondence: Mehmet Ali Șen, Dicle Üniversitesi Atatürk Sağlık Hizmetleri Meslek Yüksekokulu Diyarbakır E-posta: m.a.sen@yandex.com 


\title{
Healthy Lifestyle Behaviours of Vocational School of Health Services Students and Influential Factors
}

\begin{abstract}
Objective: The purpose of this descriptive study was to identify the healthy lifestyle behaviors of Dicle University (D.Ü.) Atatürk Vocational School of Health Services students studying in 1st year.

Methods:The research population consisted of Vocational School of Health Services 1st year students (251). A structured questionnaire including demographic data was administered to the participants and "Healthy Lifestyle Behaviors Scale II" (HLBS) organized by Walker and made Turkish validity and reliability study by Bahar et al (2008), were applied.

The data were analysed using student t- test, number-percentage calculations, mean, correlation analysis.

Results: The students' average age $20.46 \pm 3.7,70.5 \%$ female, $0.2 \%$ single, $16 \%$ student hostel, $14.7 \%$ student house, $69.3 \%$ staying with family, $27.9 \%$ moonlighting while studying, $77.7 \%$ student; their mother's level of education was found to be primary.

HLBS total point averages of students were detected to be at medium level $118.0 \pm 21.0$.Interpersonal relations avarage scores of the students whose mother has high level of education were not found to be significantly. Of those students subscales health responsibility, nutrition, interpersonal relationships average and total score was significantly high $(\mathrm{p}<0.05)$.

Conclusion: The student we studied have average HLBS score at medium level and it concluded that mother's level of education is associated with.

The students who will work in the health sector must understand the importance of health promotioning behavior and must take education to convert their knowledge into behavior.
\end{abstract}

Keywords: Lifestyle, university student, healthy lifestyle behaviors.

\section{GíRiş}

Dünya Sağlık Örgütü (DSÖ) sağlık kavramını, "sadece hastalık veya sakatlığın olmaması değil, bedensel, ruhsal ve sosyal yönden tam bir iyilik durumu" şeklinde tanımlamıştır [1].

Sağlıklı bir toplum için sağlıklı bireylerle ihtiyaç elzemdir. Bu gerekçeye göre günümüz sağlık anlayışı toplumun sağlığını korumayı, devam ettirmeyi ve geliştirmeyi amaçlar. Bu nedenle bireylere kendi sağlıklarını ve var olan iyilik hallerini koruma, idame ettirme ve geliştirme hususlarında pozitif davranışlar kazanmasına ve kendi sağllğı ile ilgili doğru kararlar almasına yardım edilmesi gerekmektedir [2-4]. DSÖ verilerine göre gelișmiş ülkelerdeki ölümlerin \%70-80' i ile, az gelişmiș ülkelerdeki ölümlerin \%40-50'sinin nedenlerinin bireylerin yaşam biçimlerine bağlı olarak ortaya çıkan davranışlar olduğu ifade edilmiştir. [4].
Sağlığın geliştirilmesi çalışmalarının amaçları arasında insanların kendi sağlıklarını düzeltme ve kontrol etmede ve dahi tam bir sağllk potansiyeline kavuşmada yeterli kılmak vardır. Bunun sonucunda ise elde edilen kazanımlar bireylerde sağllklı yaşam bilinci geliştirip bireylerin yașam tarzının iyileștirilmesi ve bir anlamda bu durum insanların sağlıklarının korunmasının kendi görevleri olduğu bilincine varmalarını sağlar. Dolaysı ile bunun sonucunda bireyler kendi yașamlarında var olan ya da var olabilecek riskli davranışlardan kaçınarak sağlı̆̆ı koruyucu ve geliștirici davranışlar kazanırlar[3].

Sağlık davranışı; sağlık, sağlığın korunması ve geliștirilmesi ile ilgili davranışlara denmektedir. Sağlığın geliştirilmesi bireyin genel sağlık ve iyilik durumunu daha da iyileştirmeyi hedefler ve sağlıklı yaşam biçimi davranışları sağlığı geliştirmeye katkıda bulunur [5]. Sağlıklı yaşam biçimi davranışları kişinin sağlık sorumluluğu, 
kendini gerçekleştirmesi, sağlık kontrolü, stres yönetimi, beslenme ve egzersiz davranışlarını içerir [4]. Walker, Sechrit ve Pender, Sağlıklı Yaşam Biçimi Davranışlarını (SYBD) "kendi kendine başlayan hareketlerin çok boyutlu modeli, iyilik seviyesini korumaya ve yükseltmeye hizmet eden algllar, kendini gerçekleştirme ve bireyselliğin tamamlanması" şeklinde tanımlamıştır [5].

Davranışların geliştirilmesi ve sürekliliğinin sağlanmasında toplumda örnek teşkil etmeleri açısından sağlık çalışanlarının önemli rol ve sorumlulukları vardır. Dolayısı ile öncelikle sağlık çalışanları kendi yaşam biçimlerini gözden geçirmeli ve düzeltmeleri gereken noktaları düzeltmelidirler [6]. Özellikle bireylerin sağlığı geliştirici davranışları istendik davranışlara çevirebilmek için bireylerin istekli olmaları ve kendilerini kontrol altında tutabilmeleri gerekmektedir. Çünkü sağlığı geliştirmek için sağlı adına olumlu davranışının kazandırılması ve bu davranışların da devam ettirilmesi gerekir. Bundan dolayıdır ki bireyin sağlığına ilişkin ileriki zamanlarda çalışma hayatına atılacak olan sağlık bölümü öğrencilerinin sağlık davranışlarını incelemek ve eksik oldukları konularda öğrencilere yardımcı olmak halk sağlığı açısından önemli bir durumdur [7]. Toplum, sağlık eğitimi alan sağlık personelinin sağlık adına yapacağı her yaşantıyı önemser ve örnek alır. Bu sebeple sağlık personellerinin ve öğrencilerinin öncelikle sağlıklı yaşam biçimi davranışları kontrol edilmeli ve eksik oldukları noktalar geliştirilmelidir. Bu bağlamda bu araştırma; D.Ü. Sağlı Hizmetleri Meslek Yüksekokulu öğrencilerinin SYBD ve etkileyen demografik özellikleri belirlemek amacıyla tanımlayıcı olarak yapılmıştır.

\section{Yöntemler}

Tanımlayıcı tipteki bu araştırmanın evrenini D.Ü. Atatürk Sağlı Hizmetleri Meslek Yüksekokulu'nun 1.sınıfında öğrenim gören öğrenciler (251 kişi) oluşturmuştur.
Araștırmaya evrenin tümü dâhil edildiğinden herhangi bir örneklem seçim yöntemi kullanılmamıştır. Araştırma kapsamına alınan öğrencilerin 166'sına ulaşılmış böylece katılım oranı \% 66.1 olmuştur. Araștırmanın verileri okul idaresinden gerekli izinler ve katılımcılardan araştırmayla ilgili bilgilendirilmiş onamları alındıktan sonra her sınıfın uygun boş ders saatinde toplanmıștır. Ulaşılamayan öğrenciler araștırmanın yapıldığı tarihlerde herhangi bir nedenle o tarihlerde okulda bulunmayan öğrencilerdir. Araştırmanın verileri, katılımcı öğrencilere yönelik bazı Tanımlayıcı Demografik Bilgiler ve SYBDÖ kullanılarak 15 Aralık 2014-15 Ocak 2015 tarihleri arasında toplanmıştır.

Tanımlayıcı Demografik Bilgiler, katılımcı öğrenciler ve aileleri hakkında tanıtıcı özelliklere ilişkin sorulardan oluşturulmuştur.

1987'de Walker, Sechrist ve Pender SYBDÖ' yü (Health Promotion Life-Style Profile) geliştirmiştir. Bunun ilk versiyonu 48 madde 6 faktörden oluşmaktadır [8]. Walker ve ark. Ölçeği tekrardan düzenlemiştir. 1996 yılında ölçek SYBDÖ II olarak adlandırılmıştır [9]. 2008 yılında Bahar ve arkadaşları tarafından Türkçe geçerlik ve güvenirlik çalışması, yapılmıştır [10]. Ölçek 52 madde ve altı faktörden oluşmaktadır. Altı faktör de sağlı sorumluluğu, fiziksel aktivite, beslenme, manevi gelişim, kişiler arası ilişkiler ve stres yönetiminden oluşmaktadır. Ölçek derecelendirmesi 4'lü likert tipindedir. Ölçekten minimum 52, maksimum 208 puan alinabilir. SYBDÖ II' nin Cronbach Alpha katsayısı. 92' dir [11].

\section{Alt faktörler:}

1.Kendini Gerçekleştirme (Manevi Gelişim); kişinin yaşam amaçlarını, bireysel olarak kendini gerçekleştirme yeteneğini ve ne derecede kişinin kendini tanıdığını ve kendini memnun ettiğini belirler. 
2.Sağlık Sorumluluğu; kişinin kendi sağlığı üzerindeki sorumluluk düzeyini ve kişinin sağlığa ne ölçüde katıldığını belirler.

3. Egzersiz (Fiziksel Aktivite); birey fiziksel aktivitelerinin ne düzeyde uygulandığını gösterir.

4.Beslenme; kişinin öğünlerini seçme, düzenleme ve yiyecek seçimindeki değerlerini belirler.

5.Kişiler Arası Destek (Kişiler Arası İlişkiler); kişinin yakın çevresi ile iletişimini ve iletişiminin süreklilik düzeyini belirler.

6.Stres Yönetimi; kişinin stres mekanizmalarını ve stres kaynaklarını tanıma düzeyini belirler [12].

Sağlıklı yaşam biçimi davranışları ölçeğindeki tüm maddeler olumludur ve 4'lü likert tipli ölçek üzerine işaretleme yapılır. Tablo 1'de SYBDÖ-II' nin alt grupları ölçekteki soru numaraları en düşük ve en yüksek puanları gösterilmiştir [6].

$\mathrm{Bu}$ çalışmada 52 maddelik SYBDÖ-II kullanılmıştır. Araștırmaya başlamadan önce öğrencilerle sözel olarak görüşülüp araştırmanın amacı anlatılmış ve araștırmaya gönüllü olanlar dâhil edilmiştir. Anket formları öğrencilerin derslerini aksatmayacak biçimde uygun zamanlarda uygulanmıştır.

\section{Verilerin değerlendirilmesi:}

Veriler araştırmacılar tarafından PASW Statistics 18.0 (SPSS 18.0) programında değerlendirildi. Verilerin istatistiksel analizinde sayı-yüzdelik hesaplama, ortalama ve $t$ testi kullanıldı. Ortalamalar standart sapma ile birlikte verilip (Ort. $\pm S S$ ), $\mathrm{p}<0.05$ istatistiksel anlamlılık olarak değerlendirildi.

\section{BULGULAR}

Araștırmaya katılan 166 öğrencinin yaş ortalaması 20,46 $\pm 3,7^{\prime}$ dir. Öğrencilerin \%70.5'i kadın, \%29,5'i erkek öğrenci olup, \%90,2'i bekar, ve \%9,8' i evlidir. Öğrencilerin, \%69,3'ü ailelerinin yanında kalırken \%16'sı yurt, \%14,7'si de öğrenci evinde kalmaktadırlar. Öğrencilerin \%27,9'u okurken aynı zamanda ek bir işte çalışmaktadır. Öğrenciler ekonomik durumlarını kendi ifadelerine göre \% 4,9'u yoksul, \% 25'i dar gelirli, \%55,5'i orta düzey, \% 13,4 'ü iyi ve \%1,2'sininde gelir düzeyi yüksek olarak tanımlamışlardır. Öğrencilerin annelerinin eğitim durumu \%49,4 okuryazar değil, \%28,3 ilkokul mezunu, \%13,3 ortaokul mezunu, \%7,2 lise mezunu, \%1,2 lisan mezunu, $\% 0,6$ lisansüstü mezunu şeklindedir. Babalarının eğitim durumu ise sırasıyla \%10,4, $\% 32,5, \% 20,9, \% 27, \% 2,5$ ve $\% 1,8$ șeklindedir (Tablo2).

Araştırmaya katılan öğrencilerin SYBD ölçeğine göre aldıkları toplam puanların ortalaması $118,01 \pm 21,0$ (alt puan=61; üst puan=169)'dır. Öğrencilerin SYBD alt ölçeklerinden aldıkları puan ortalamalarına baktığımızda; en yüksek

Tablo 1: SYBDÖ-II'nin alt grupları ölçekteki soru numaraları en düşük ve en yüksek puanları

\begin{tabular}{llcc}
\hline Alt Gruplar & Ölçekteki Soru Numaraları & En Düşük Puan & En Yüksek Puan \\
Kendini Gerçekleştirme & $6,12,18,24,30,36,42,48,52$ & 9 & 36 \\
Sağlık Sorumluluğu & $3,9,15,21,27,33,39,45,51$ & 9 & 36 \\
Egzersiz & $4,10,16,22,28,34,40,46$ & 8 & 32 \\
Beslenme & $2,8,14,20,26,32,38,44,50$ & 9 & 36 \\
Kişiler arası Destek & $1,7,13,19,25,31,37,43,49$ & 9 & 36 \\
Stres Yönetimi & $5,11,17,23,29,35,41,47$ & 8 & 32 \\
Sağlıklı Yaşam Biçimi Davranışları & $1-52 . m a d d e l e r$ & 52 & 208 \\
\hline
\end{tabular}

Yalçınkaya M, Özer F.G, Karamanoğlu A.Y. Sağlık Çalışanlarında Sağlıklı Yaşam Biçimi Davranışlarının Değerlendirilmesi TSK Koruyucu Hekimlik Bülteni, 2007: 6 (6): 409-420. (6) 
Tablo 2: Öğrencilerin Tanımlayıcı Özelliklerinin Dă̆ılımı

\begin{tabular}{|c|c|c|c|c|c|}
\hline Tanıtıcı Özellikler & $\mathbf{S}$ & $\%$ & & $\mathbf{S}$ & $\%$ \\
\hline İkamet Yeri & & & Anne Eğitim Durumu & & \\
\hline Aile Evi & 113 & 69,3 & Okur yazar değil & 82 & 49,4 \\
\hline Yurt & 26 & 16,0 & İlkokul & 47 & 28,3 \\
\hline \multirow[t]{2}{*}{ Öğrenvi Evi } & 24 & 14,7 & Ortaokul & 22 & 13,3 \\
\hline & & & Lise & 12 & 7,2 \\
\hline \multirow[t]{2}{*}{ Toplam } & 163 & 100,0 & Lisans & 2 & 1,2 \\
\hline & & & Lisansüstü & 1 & 0,6 \\
\hline Cinsiyet & & & Toplam & 166 & 100,0 \\
\hline Erkek & 49 & 29,5 & & & \\
\hline Kadın & 117 & 70,5 & Baba Eğitim Durumu & & \\
\hline \multirow[t]{2}{*}{ Toplam } & 166 & 100,0 & Okur yazar değil & 17 & 10,4 \\
\hline & & & İlkokul & 53 & 32,5 \\
\hline Medeni Durum & & & Ortaokul & 34 & 20,9 \\
\hline Evli & 16 & 9,8 & Lise & 44 & 27 \\
\hline \multirow[t]{2}{*}{ Bekar } & 147 & 90,2 & Önlisans & 8 & 4,9 \\
\hline & & & Lisans & 4 & 2,5 \\
\hline Toplam & 163 & 100,0 & Lisansüstü & 3 & 1,8 \\
\hline Ailenin Eko. Durumu & & & Toplam & 166 & 100,0 \\
\hline Yoksul & 8 & 4,9 & $\begin{array}{l}\text { Okurken Ek Bir İşte } \\
\text { Çalışıyor mu }\end{array}$ & & \\
\hline Dar gelirli & 41 & 25,0 & Hayır & 119 & 72,1 \\
\hline Orta düzey & 91 & 55,5 & Evet & 46 & 27,9 \\
\hline İyi & 22 & 13,4 & & & \\
\hline Yüksek & 2 & 1,2 & Toplam & 165 & 100,0 \\
\hline Toplam & 164 & 100,0 & & & \\
\hline
\end{tabular}

*. 3 katılımcı ikamet yeri, 3 katılımcı medeni durum, 3 katılımcı baba eğitim durumu, 2 katılımcı aileni ekonomik durumu ve 1 katılımcı ek işte çalışma durumu sorularına cevap vermemiștir.

Tablo 3: Öğrencilerin SYBDÖ-II Alt Gruplarından Aldıkları Puanların Ortalamaları

\begin{tabular}{lccc}
\hline SYBDÖ Alt Grupları & N & Min-Mak & Ort \pm SS \\
\hline Manevi Gelişim & 144 & $12-35$ & $23,44 \pm 5,2$ \\
Sağlık Sorumluluğu & 126 & $9-31$ & $18,90 \pm 4,4$ \\
Fiziksek Aktivite & 152 & $8-28$ & $15,25 \pm 4,7$ \\
Beslenme & 142 & $9-31$ & $18,46 \pm 4,1$ \\
Kişilerarası İlişki & 137 & $11-36$ & $23,44 \pm 5,2$ \\
Stres Yönetimi & 147 & $10-28$ & $17,41 \pm 3,5$ \\
SYBDÖ Toplam Puanı & 89 & $61-169$ & $118,01 \pm 21,0$ \\
\hline
\end{tabular}


puan manevi gelișim ve kișilerarası ilișkiler $(23,44 \pm 5,2)$ daha sonra sirasiyla sağlık sorumluluğu $(18,90 \pm 4.4)$, beslenme $(18,46 \pm$ $4,1)$, stres yönetimi $(17,41 \pm 3.5)$ ve fiziksel aktiviteden $(15,25 \pm 4.7)$ almıştır (Tablo 3 ).

Cinsiyete göre SYBD ölçeği puan ortalamaları incelendiğinde fiziksel aktivite alt grubu puan ortalaması erkek öğrencilerde $(16,83 \pm 4,4)$, kız öğrencilerde ise $(14,67 \pm 4,7)$ bulunmuştur (p>0.05). Aynı şekilde sırasıyla sağlık sorumluluğu puan ortalaması $(18,83 \pm 3,9)$ ve $(18,93 \pm 4,6)$ beslenme puan ortalaması $(19,26 \pm 4,6)$ ve $(18,13 \pm 3,9)$, kişilerarası ilişkiler puan ortalaması $(22,86 \pm 5,0)$ ve $(23,65 \pm 5,2)$, stres yönetimi puan ortalaması $(17,65 \pm 3,0)$ ve $(17,32 \pm 3,6)$ manevi gelişim puan ortalaması $(24,40 \pm 5,2)$ ve $(24,70 \pm 5,3)$ bulunmuştur (Tablo 4).

Tablo 4: Öğrencilerin Cinsiyetlerine Göre SYBDÖ Alt Ölçek Puan Ortalamalarının Dağılımı

\begin{tabular}{ccc}
\hline SYBD Alt Ölçekleri & \multicolumn{2}{c}{ Cinsiyet Anlamlılık Derecesi } \\
& Ortalama \pm SD & P \\
\hline $\begin{array}{c}\text { Sağlık Sorumluluğu } \\
\text { Erkek(S=37) }\end{array}$ & $18,83 \pm 3,9$ & 0.91 \\
Kadın(S=89) & $18,93 \pm 4,6$ & \\
Fiziksel Aktivite & & \\
Erkek(S=43) & $16,83 \pm 4,4$ & 0,09 \\
Kadın(S=109) & $14,62 \pm 4,7$ & \\
Beslenme & & \\
Erkek(S=42) & $19,26 \pm 4,6$ & 0,13 \\
Kadın(S=100) & $18,13 \pm 3,9$ & \\
Kişilerarası İlişkiler & & \\
Erkek(S=36) & $22,86 \pm 5,0$ & 0,43 \\
Kadın(S=101) & $23,65 \pm 5,2$ & \\
\hline Stresle Yönetimi & & \\
Erkek(S=41) & $17,65 \pm 3,0$ & 0,60 \\
Kadın(S=106) & $17,32 \pm 3,6$ & \\
Manevi Gelişim & \\
Erkek(S=42) & $24,40 \pm 5,2$ & \\
Kadın(S=102) & $24,70 \pm 5,3$ & 0,75 \\
Toplam & & \\
Erkek(S=26) & $119,07 \pm 21,9$ & 0,76 \\
Kadın(S=63) & $117,57 \pm 2,7$ & \\
\hline & & \\
\hline
\end{tabular}

Okurken ek bir işte çalıșma durumuna göre SYBD ölçeği puan ortalamaları karşılaştırıldığında; çalışan öğrencilerin sağlık sorumluluğu, fiziksel aktivite, beslenme, kișilerarası ilișkiler stres yönetimi ve manevi gelişim alt grubu puan ortalamaları çalışmayan öğrencilerin alt grup puan ortalamaları arasında istatistiksel açıdan anlamlı bulunmamıştır ( $>0.05$ ) (Tablo 5).

Tablo 5: Öğrencilerin Okurken Ek Bir İște Çalıșma Durumuna Göre SYBDÖ Alt Ölçek Puan Ortalamalarının Dağılımı

\begin{tabular}{|c|c|c|}
\hline SYBD Alt Ölçekleri & $\begin{array}{c}\text { SYBDÖ } \\
\text { Ortalama } \pm S D\end{array}$ & $\begin{array}{c}\text { Anlamlılık } \\
\text { Derecesi } \\
\text { P }\end{array}$ \\
\hline \multicolumn{3}{|l|}{ Sağlık Sorumluluğu } \\
\hline Evet $(S=37)$ & $19,45 \pm 4,6$ & \multirow[t]{2}{*}{0,36} \\
\hline Hayır $(S=89)$ & $18,67 \pm 4,3$ & \\
\hline \multicolumn{3}{|l|}{ Fiziksel Aktivite } \\
\hline Evet $(S=44)$ & $15,97 \pm 5,1$ & \multirow[t]{2}{*}{0,22} \\
\hline Hayır(S=108) & $14,95 \pm 4,6$ & \\
\hline \multicolumn{3}{|l|}{ Beslenme } \\
\hline Evet $(S=40)$ & $18,82 \pm 4,8$ & \multirow[t]{2}{*}{0,51} \\
\hline Hayır(S=102) & $18,32 \pm 3,9$ & \\
\hline \multicolumn{3}{|l|}{ Kişilerarası İlișkiler } \\
\hline Evet $(S=35)$ & $24,14 \pm 4,8$ & \multirow[t]{2}{*}{0,35} \\
\hline Hayır $(S=102)$ & $23,20 \pm 5,3$ & \\
\hline \multicolumn{3}{|l|}{ Stres Yönetimi } \\
\hline Evet(S=42) & $17,09 \pm 3,7$ & \multirow{2}{*}{0,48} \\
\hline Hayır $(S=105)$ & $17,54 \pm 3,4$ & \\
\hline \multicolumn{3}{|l|}{ Manevi Gelişim } \\
\hline Evet(S=42) & $25,72 \pm 4,8$ & \multirow[b]{2}{*}{0,09} \\
\hline Hayır $(S=105)$ & $24,14 \pm 5,3$ & \\
\hline \multicolumn{3}{|l|}{ Toplam } \\
\hline Evet $(S=28)$ & $117,17 \pm 20,3$ & \multirow{2}{*}{0,80} \\
\hline Hayır $(S=61)$ & $118,39 \pm 21,4$ & \\
\hline
\end{tabular}

Tablo 6 de öğrencilerin medeni durumuna göre SYBD ölçeği puan ortalamaları karşılaştırılmıștır. Buna göre evli öğrencilerin sağlık sorumluluğu, fiziksel aktivite, beslenme, kişilerarası ilişkiler, stres yönetimi ve manevi gelişim alt grupları puan ortalamaları, evli olmayanlara göre yüksek olmakla birlikte istatistiksel açıdan anlamlı değildir( $(p>0.05)$.

Öğrencilerin ailelerinin gelir durumuna göre SYBD ölçeği puan ortalamaları tablo $7 \mathrm{de}$ verilmiștir. Buna göre ailelerinin gelir durumu yüksek olan öğrencilerin fiziksel aktivite alt grupların puan ortalaması $(17,04 \pm 4,9)$, gelir 
durumu orta olan öğrencilerin alt grup puan ortalaması $(14,70 \pm 4,7)$ olup gruplar arasındaki fark istatistiksel olarak anlamlıdır( $p=0,04)$. Diğer alt grup puan ortalamaları (sağlık sorumluluğu, beslenme, kişilerarası ilişkiler, stres yönetimi ve manevi gelişim) ailelerin geliri yüksek olan öğrencilerin ailelerinin geliri orta düzeyde olanlara göre daha yüksek ancak istatistiksel olarak göre anlamlı değildir (Tablo7).Anne eğitim durumuna göre SYBD ölçeği puan ortalamaları karşılaştırıldığında; annenin mezun olduğu okul derecesi en az ortaokul olan öğrencilerin beslenme, kişilerarası ilişkiler, alt gruplarının puan ortalaması ve toplam puan ortalaması anne mezuniyeti ilkokul olan öğrencilerin alt grup puan ortalamasına göre istatistiksel açıdan anlamlı derecede yüksek bulundu $(\mathrm{p}<0.05)$ (Tablo 8).

Tablo 6: Öğrencilerin Medeni Durumuna Göre SYBDÖ Alt Ölçek Puan Ortalamalarının Dağılımı

\begin{tabular}{lcc}
\hline \multirow{2}{*}{ SYBD Alt Ölçekleri } & \multicolumn{2}{c}{ Medeni Durum } \\
& Anlamlılık Derecesi \\
& Ortalama \pm SD & p \\
\hline Sağlık Sorumluluğu & & \\
$\quad$ Evli(S=14) & $19,21 \pm 4,2$ & 0.78 \\
Bekar(S=112) & $18,86 \pm 4,4$ & \\
Fiziksel Aktivite & & \\
Evli(S=14) & $16,92 \pm 6,2$ & 0,16 \\
Bekar(S=138) & $15,07 \pm 4,5$ & \\
Beslenme & & \\
Evli(S=16) & $20,06 \pm 5,8$ & \\
Bekar(S=126) & $18,26 \pm 3,9$ & 0,10 \\
Kişilerarası İlişkiler & & \\
Evli(S=12) & $24,33 \pm 4,5$ & 0,53 \\
Bekar(S=125) & $23,36 \pm 5,3$ & \\
\hline Stresle Yönetimi & & \\
Evli(S=14) & $18,21 \pm 3,7$ & 0,37 \\
Bekar(S=133) & $17,33 \pm 3,5$ & \\
Manevi Gelişim & & \\
Evli(S=14) & $26,57 \pm 4,1$ & 0,14 \\
Bekar(S=130) & $24,40 \pm 5,3$ & \\
Toplam & & \\
Evli(S=8) & $125,37 \pm 23,9$ & 0,30 \\
Bekar(S=81) & $117,28 \pm 20,7$ & \\
\hline
\end{tabular}

\section{TARTIȘMA}

Dünya Sağlık Örgütü (DSÖ) tahminlerine göre gelişmiş ülkelerdeki ölümlerin \%70-80' inin, gelişmekte olan ülkelerdeki ölümlerin \%4050'sinin nedeni, yaşam biçimine bağlı olarak ortaya çıan hastalıklardır. Bu hastalıkların oluşumunda kişinin kendi tutum ve davranışlarının rolü büyüktür. $\mathrm{Bu}$ durum hastalıklardan korunma ve sağlığın geliştirilmesinde en önemli etken olan yaşam şekillerinin geliştirilmesine yönelik uygulamaların önemini ortaya çıkarmaktadır. Öte yandan sağlığın geliştirilmesi ve hastanın sağlıklı davranışlar konusunda bilgilendirilmesini ve yönlendirilmesini sağlayacak grup, sağllk profesyonelleri ve sağlık danışmanlarıdır.

Sağlık çalışanları, mesleki sorumlulukları ve sosyal rolleri gereği sürdürdükleri yaşam biçimleri ile rol modeli olma ve sağlık eğitimi yönünden hizmet verdikleri grubu etkileme özelliğine sahiptir. Bundan dolayı sağllğı geliştirme aktivitelerinde sağllk profesyonellerine büyük sorumluluklar düşmektedir.

Çalışmamızda en yüksek puan ortalaması manevi gelişim ve kişilerarası ilişkiler $(23,44 \pm$ 5,2 ) alt grubunda bulunmuştur. En düşük puan ortalaması ise bazı çalışmalar da olduğu gibi [3, $13,14]$ fiziksel aktivite alanında $(15,25 \pm 4.7)$ bulunmuştur. Öğrencilerin fiziksel aktvitelerinin yüksek sayllabileceği üniversite yıllarında bu kadar sedanter yaşam içinde olmaları düşündürücüdür.

İlerde sağlık profesyoneli olarak çalışacak olan sağlık hizmetleri meslek yüksekokulu öğrencileri arasında yapılan bu çalışmada öğrencilerin SYBD ölçeği ortalamasının orta düzeyde olduğu bulunmuştur. Öğrencilerin SYBD ölçeği puan ortalamasının toplamı 118,01 $\pm 21,0$ bulunmuştur. Hemşirelik yüksekokulu öğrencilerinin sağlı̆̆ geliştirme davranışlarını ölçen bir çalışmalarda da SYBD ölçeği puanı;

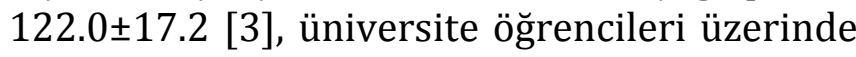
yapılan çalışmada $125.9 \pm 17.4 \quad[4]$, birinci basamak sağlık hizmetlerinde çalışan sağlık 
Tablo 7: Öğrencilerin Ailelerinin Gelir Durumuna Göre SYBDÖ Puan Ortalamaları Dağılımı

\begin{tabular}{|c|c|c|}
\hline \multirow[t]{2}{*}{ SYBD Alt Ölçekleri } & \multicolumn{2}{|c|}{ Gelir Karşılaş̧tırması Anlamlılık Derecesi } \\
\hline & Ortalama $\pm S D$ & $\mathbf{p}$ \\
\hline \multicolumn{3}{|l|}{ Sağlık Sorumluluğu } \\
\hline Orta Düzey Gelir(S=67) & $18,76 \pm 3,9$ & \multirow{2}{*}{0,65} \\
\hline Yüksek Gelir (S=18) & $19,27 \pm 5,7$ & \\
\hline \multicolumn{3}{|l|}{ Fiziksel Aktivite } \\
\hline Orta Düzey Gelir(S=82) & $14,70 \pm 4,7$ & \multirow{2}{*}{0,04} \\
\hline Yüksek Gelir (S=21) & $17,04 \pm 4,9$ & \\
\hline \multicolumn{3}{|l|}{ Beslenme } \\
\hline Orta Düzey Gelir(S=76) & $18,11 \pm 3,7$ & \multirow{2}{*}{0,26} \\
\hline Yüksek Gelir (S=21) & $19,19 \pm 4,7$ & \\
\hline \multicolumn{3}{|l|}{ Kişilerarası İlişkiler } \\
\hline Orta Düzey Gelir(S=72) & $23,25 \pm 5,2$ & \multirow[t]{2}{*}{0,70} \\
\hline Yüksek Gelir (S=21) & $23,76 \pm 6,3$ & \\
\hline \multicolumn{3}{|l|}{ Stresle Yönetimi } \\
\hline Orta Düzey Gelir(S=80) & $17,16 \pm 3,5$ & \multirow{2}{*}{0,36} \\
\hline Yüksek Gelir (S=21) & $18,00 \pm 4,5$ & \\
\hline \multicolumn{3}{|l|}{ Manevi Gelişim } \\
\hline Orta Düzey Gelir(S=78) & $24,75 \pm 5,5$ & \multirow{2}{*}{0,77} \\
\hline Yüksek Gelir (S=20) & $25,15 \pm 5,4$ & \\
\hline \multicolumn{3}{|l|}{ Toplam } \\
\hline Orta Düzey Gelir(S=46) & $115,43 \pm 20,9$ & \multirow{2}{*}{0,49} \\
\hline Yüksek Gelir (S=15) & $120,06 \pm 26,9$ & \\
\hline
\end{tabular}

Tablo 8: Anket Yapılan Öğrencilerin Anne Eğitim Durumuna Göre SYBDÖ Puan Ortalamaları ve Alt Ölçek Puan Ortalamalarının Dağılımı

\begin{tabular}{|c|c|c|}
\hline \multirow[t]{2}{*}{ SYBD Alt Ölçekleri } & \multicolumn{2}{|c|}{ Gelir Karşılaştırması Anlamlılık Dereces } \\
\hline & Ortalama \pm SD & $\mathbf{p}$ \\
\hline \multicolumn{3}{|l|}{ Sağlık Sorumluluğu } \\
\hline En Fazla İlkokul Mezunu (S=101) & $18,60 \pm 4,3$ & \multirow{2}{*}{0,07} \\
\hline En Az Ortaokul Mezunu (S=25) & $20,12 \pm 4,6$ & \\
\hline \multicolumn{3}{|l|}{ Fiziksel Aktivite } \\
\hline En Fazla İlkokul Mezunu (S=118) & $15,07 \pm 4,7$ & \multirow{2}{*}{0,37} \\
\hline En Az Ortaokul Mezunu ( $S=34)$ & $15,85 \pm 4,8$ & \\
\hline \multicolumn{3}{|l|}{ Beslenme } \\
\hline En Fazla İlkokul Mezunu (S=111) & $18,09 \pm 4,2$ & \multirow{2}{*}{0,01} \\
\hline En Az Ortaokul Mezunu (S=31) & $19,80 \pm 3,8$ & \\
\hline \multicolumn{3}{|l|}{ Kişilerarası İlişkiler } \\
\hline En Fazla İlkokul Mezunu (S=105) & $22,67 \pm 4,7$ & \multirow[t]{2}{*}{0,02} \\
\hline En Az Ortaokul Mezunu (S=32) & $25,96 \pm 5,9$ & \\
\hline \multicolumn{3}{|l|}{ Stresle Yönetimi } \\
\hline En Fazla İlkokul Mezunu (S=114) & $17,19 \pm 3,0$ & \multirow{2}{*}{0,14} \\
\hline En Az Ortaokul Mezunu (S=33) & $18,18 \pm 4,7$ & \\
\hline \multicolumn{3}{|l|}{ Manevi Gelişim } \\
\hline En Fazla İlkokul Mezunu (S=111) & $24,03 \pm 5,0$ & \multirow{2}{*}{0,07} \\
\hline En Az Ortaokul Mezunu (S=33) & $26,57 \pm 5,6$ & \\
\hline \multicolumn{3}{|l|}{ Toplam } \\
\hline En Fazla İlkokul Mezunu (S=69) & $115,0 \pm 19,1$ & \multirow{2}{*}{0,00} \\
\hline En Az Ortaokul Mezunu (S=20) & $128,6 \pm 24,0$ & \\
\hline
\end{tabular}


personeli çalıșmasında 117.5 \pm 17.1 [15], Ünalan D. ve ark.' nın [16] bir grup sağlık yüksek okulu öğrencileri arasında yaptıkları çalışmada da $127.8 \pm 17.5$ olarak saptanmıştır. Ülkemizde 2008'de yapılan bir başka çalışmada SYBD-I ölçeğinin toplam puanı 125.96 \pm 16.99 bulunmuștur [14]. Türkiye'de aynı ölçekle yapılan çalışmaların sonuçları genellikle benzerlik göstermektedir. Choi Hui (2002)'nin Hong Kong'da hemşirelik öğrencilerinde yapmış olduğu çalışmasında SYBDÖ toplam puanı bizim çalışmamıza göre az da olsa düşük (116) bulunmuştur [13]. Yurt dişında yapılan bazı çalışmalarda ise daha düşük SYBD puanları elde edilmiştir $[17,18]$.

Çalışmamızda arasında istatistiksel olarak anlamlı fark olmamasına karşın erkek öğrencilerin SYBD puanlarının kız öğrencilere göre daha yüksek olduğu saptanmıştır. Aynı şekilde Pasinlioğlu ve Gözüm' ün yaptıkları çalışmasında cinsiyete göre SYBD puanları sonucu orta düzeyde bulunmuş ve kadın ve erkek arasında istatistiksel olarak anlamlı fark bulunmamıştır [15]. Kaya ve ark. da [19] öğretim elemanları üzerinde yaptıkları araştırmada SYBD ile cinsiyet arasında anlamlı bir ilişki saptayamamışlardır. Aynı şekilde AlKandari (2007) ve Choi Hui (2002) hemşirelik öğrencileri üzerinde yaptıkları çalışmalarda onlarda da genel toplam puan ile cinsiyet arasında anlamlı fark bulunmamıştır $[13,20]$. Pasinoğlu ve Gözüm'ün [15] çalışmalarında kadınların SYBD beslenme alt grup puan ortalamalarının erkeklerden anlamlı olarak daha yüksek olduğunu bildirmișlerdir. Özbaşaran ve arkadaşlarının 2004 yılı yüksekokul öğrencileri üzerinde yapılan çalışmasında da kız öğrencilerin SYBDÖ puan ortalamaları erkeklere göre daha yüksek bulunmuștur [21]. Yapılan araștırmalarda da görüldüğü gibi cinsiyet ve SYBD arasında bizim bulduğumuz sonuçlar ile benzer ve farklı sonuçlar elde edilmiştir.
Annenin mezun olduğu okul derecesi en az ortaokul olan öğrencilerin beslenme, kişilerarası ilişkiler, alt gruplarının puan ortalaması ve toplam puan ortalaması anne mezuniyeti ilkokul olan öğrencilere göre istatistiksel açıdan anlamlı derecede yüksek bulundu. Aynı şekilde farklı ülkelerde yapılan bazı çalışmalarda anne baba eğitim durumunun SYBD' yi etkilediği bildirilmiştir [3, 22, 23]. Karadeniz ve ark.'nın [4] yaptıkları çalışmada da öğrencilerin anne-baba eğitim durumu ile SYBD ölçeği arasında anlamlı fark bulunmamıștır. Türkiye'de yapılan çalışmalarda anne-baba eğitiminin SYBD 'ye etkisi konusunda bildirilen sonuçlar değiş̧iklik göstermektedir.

Nedensel gereklilikler dışında kişilerle anlamlı bir ilişki kurabilmek için iletişim önemlidir. İletişim ve başkaları ile ilişsi kurma iç huzuru sağlar, kim olduğumuz ve yaptığımız şeyin dışında daha başka yeni deneyimler için firsat sağlama olasılı̆̆ını yaratır. Çalışmamızda anne eğitim durumu yüksek olan öğrencilerin kişilerarası ilişki SYBD alt grup puan ortalaması, anne eğitim durumu düşük olan öğrencilere göre yüksek bulunmuştur $(p=0,02) . B u$ da gösteriyor ki eğitim düzeyi yüksek annelerin çocukları üzerinde de model aldıkları ebeveynlerine paralel olarak bu alt grup faktörlerin daha yüksek olabileceği söylenebilir.

Yükseköğrenim sırasında ekonomik olarak yeterli bir gelirin olması, ek bir yerde çalışmak, sosyal aktivite içinde olmak gibi örneklerin öğrencinin manevi gelişimine katkı sunabilir. Çalışmamızda öğrencilerin okurken ek bir işte çalışıp çalışmamalarının SYBD ölçeği puanlarını etkileyip etkilemediği sorgulanmış olup çalışanların manevi gelişim SYBD alt ölçeği ortalama puanı çalıșmayanlara göre yüksek olmakla birlikte istatistiksel açıdan anlamlı bulunmadı. Çalışmamızın sonuçlarına benzer olarak, ülkemizde yapılan bir çalışmada öğrencilerin aylık gelirlerine göre SYBD ölçeği ve alt grupları puan ortalamaları arasında 
anlamlı bir fark bulunmamıștır [5]. Yine ülkemizde yapılan başka bir çalışmada da öğrencilerin gelir durumlarının SYBD ölçeği puanlarını anlamlı düzeyde etkilediğini bulmuşlardır $(p<0,001)$ [21].Ekonomik etkenler kişilerin SYBD 'lerini pozitif yönde etkileyebileceği gerçeği çeşitli araştırmaların sonuçları ile de doğrulanmaktadır.

Sonuç olarak;

Gerek yapmış olduğumuz çalışma ve ülkemizde yapılan diğer genel olarak üniversite öğrencilerinin SYBD puan ortalamalarının orta düzeyde olduğu sonucuna ulaşılmıştır. Bu sonuç gelişmekte olan ülkemiz açısından iyi olarak değerlendirilebilir. Ancak bizim araştırmamızın örneklemini geleceğin sağllk teknikerlerinin oluşturması ve araştırmanın sonucunun da orta düzeyde çıkması onlardan beklenen sağlıklı, entelektüel ve bilișsel yeteneklerin yeterince kazanılamadığını göstermektedir. Ayrıca çalışmamız sonucunda;

Alt ölçeklerde en yüksek puan manevi gelişim ve kişilerarası ilişkilere ait iken en düşük puan fiziksel aktiviteye ait olarak tespit edilmiştir.

Erkek öğrencilerin SYBD puanlarının anne eğitim durumu yüksek olan öğrencilerin kişilerarası ilişki alt grupların puan ortalaması, ek bir iște alışanların manevi gelişim SYBD alt ölçeği puan ortalaması daha yüksektir.

Dolayısı ile toplumda sağlıklı yaşam konusunda örnek teşkil edecek olan sağlık alanındaki personel ve öğrencilerin konuyla ilgili olumsuz ya da eksik davranışlarını düzelterek iyi bir rol modeli olması için çalışmaların yapılmalı,

Sağlık meslek yüksekokullarının müfredatlarına sağlıklı yaşam biçimi davranışlarını geliştirmeye yönelik ders veya derslerin konulmalı ve ayrıca sağlık davranışları ve sağlık davranışı üzerinde etkili olan faktörlere yönelik olarak daha geniş örneklemi kapsayan araştırmaların yapılması önerilebilir.
Bu çalışma 18.Ulusal Halk Sağlığı Kongresinde poster bildiri olarak sunulmuştur. (5-9 Ekim 2015 KONYA) Temel Halk Sağlığı POSTER BILLIRİ -322

Çıkar Çatışması Beyanı: Yazarlar çıkar çatışması olmadığını bildirmişlerdir.

Finansal Destek: Bu çalışma her hangi bir fon tarafından desteklenmemiştir.

Declaration of Conflicting Interests: The authors declare that they have no conflict of interest.

Financial Disclosure: No financial support was received.

\section{KAYNAKLAR}

1. WHO- Constitution, International Health Watch, http://www.ldb.org/iphw/whoconst.htm\#1

2. Oyur Çelik G, Malak A.T, Bektaş M, ve ark. Sağlık yüksekokulu öğrencilerinin sağlığı geliştirme davranışlarını etkileyen etmenlerin incelenmesi Anatol J Clin Investig 2009:3:164-9.

3. Ayaz S, Tezcan S, Akıncı F. Hemşirelik yüksekokulu öğrencilerinin sağlığı geliştirme davranışları. Cumhuriyet Üniversitesi Hemşirelik Yüksek Okulu Dergisi. 2005;9: 26-34.

4. Karadeniz G, Uçum EY, Dedeli Ö, Karaağaç Ö. Üniversite Öğrencilerinin Sağlıklı Yaşam Biçimi Davranışları. TAF Prev Med Bull. 2008; 7:497-502.

5. Ünalan D, Şenol V, Öztürk A. ve ark. Meslek Yüksekokullarının Sağlık ve Sosyal Programlarında Öğrenim Gören Öğrencilerin Sağlıklı Yaşam Biçimi Davranışları ve Öz-Bakım Gücü Düzeyleri Arasındaki İlişkinin İncelenmesi. İnönü Üniversitesi Tıp Fakültesi Dergisi 2007;14;101-9.

6. Yalçınkaya M, Özer F.G, Karamanoğlu A.Y. Sağlık Çalışanlarında Sağlıklı Yaşam Biçimi Davranışlarının Değerlendirilmesi TSK Koruyucu Hekimlik Bülteni, 2007:6:409-20

7. İlhan N, Batmaz M, Akhan L.U. Üniversite öğrencilerinin sağlıklı yaşam biçimi davranışları 23-26 Ekim 2007'de Denizli'de II. Ulusal Halk Sağlığı Kongresinde Poster Bildiri(Maltepe Üniversitesi Hemşirelik Bilim ve Sanatı Dergisi, Cilt:3, Sayı:3 2010). 
8. Walker SN, Sechrist KR, Pender NJ. The healthpromoting lifestyle profile: development and psychometric characteristics. Nurs Res 1987; 36: 76-81.

9. Walker SN, Hill-Polerecky DM (1996) Psychometric evaluation of the Health Promoting Lifestyle Profile II. Unpublished manuscript, University of Nebraska Medical Center.

10. Bahar Z, Beşer A, Gördes N, ve ark. (2008). Sağllklı yaşam biçimi davranışları ölçeği II'nin geçerlik ve güvenirlik çalışması. Cumhuriyet Üniversitesi Hemşirelik Yüksekokulu Dergisi 12: 1-13.

11. Özyazıcıoğlu N, Kılıç M, Erdem N, ve ark. (2011). Hemşirelik öğrencilerinin sağlıklı yaşam biçimi davranıșlarının belirlenmesi. (Bu çalıșma 9. Uluslararası Katılımlı Ulusal Hemşirelik Öğrencileri Kongresi'nde "Sağlığa duyarlılık" oturumunda sunulmuştur (Fethiye/ Muğla-2010)). Uluslararası İnsan Bilimleri Dergisi [Bağlantıda]. 8:2, Erişim: http://www.InsanBilimleri.com

12. Esin N (1997). Endüstriyel Alanda Çalışan İşçilerin Sağlık davranışlarının Saptanması ve Değiștirilmesi, Doktora Tezi, İstanbul Üniv. Sağlık Bilimleri Enstitüsü, İstanbul.

13. Hui, WHC. (2002). The health-promoting lifestyles of undergraduate nurses in Hong Kong. J Prof Nurs 18: 101-11.

14. Özkan S, Yılmaz E. (2008). Hastanede Çalışan Hemşirelerin Sağlıklı Yaşam Biçimi Davranışları. Fırat Sağlık Hizmetleri Dergisi 3: 89-105.

15. Pasinlioğlu P, Gözüm S. Birinci Basamak Sağllk Hizmetlerinde Çalışan Sağlık Personelinin Sağlık Davranışları. Cumhuriyet Üniversitesi Hemşirelik Yüksekokulu Dergisi. 1998; 2:60-8.
16. Ünalan D, Öztop DB, Elmalı F, ve ark. Bir grup sağlık yüksekokulu öğrencisinin yeme tutumları ile sağlıklı yaşam biçimi davranışları arasındaki ilişki. İnönü Üniversitesi Tıp Fakültesi Dergisi 2009; 16:75-81.

17. Bagwell MM, Bush HA. Improving health promotion for blue collar workers. J Nurs Care Qual 2000; 14:65-71.

18. Tashiro J. Exploring health promoting lifestyle behaviors of Japanese college women; perceptions, practices, and issues.Health Care Women Int 2002; 23:59-70.

19. Kaya $F$, Ünüvar $R$, Bıçak $A$, ve ark. Öğretim elemanlarının sağlığı geliştirme davranışları ve etkileyen etmenlerin incelenmesi. TSK Koruyucu Hekimlik Bülteni 2008; 7:59-64.

20. Al-Kandari F, Vidal VL. (2007). Correlation of the health-promoting lifestyle, enrollment level, and academic performance of College of Nursing students in Kuwait. Nurs Health Sci. 9:112-9.

21. Özbaşaran F, Çakmakçı Çetinkaya A, Güngör N. Celal Bayar Üniversitesi Sağlık Yüksekokulu öğrencilerinin sağlık davranışları. Atatürk Üniversitesi Hemşirelik Yüksekokulu Dergisi 2004; 7:43-55.

22. Weitzel MH. A test of the health promotion model with blue collar workers. Nursing Research. 1989; 38:99-104.

23. Lusk SL, Kerr MJ, Ronis DV. Health-promoting lifestyles of blue-collar, skilled trade, and whitecollar workers. Nursing Research. 1995; 44:20-4. 
Dicle Tıp Dergisi / Dicle Medical Journal

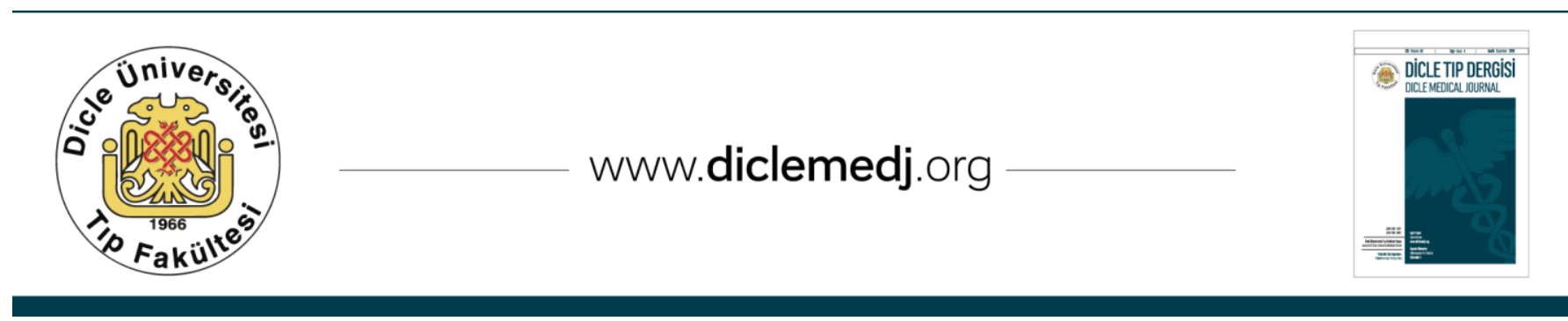

